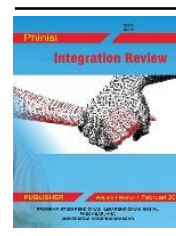

Phinisi Integration Review

Vol. 2, No.2, Agustus 2019 Hal 227-237

Website: http://ojs.unm.ac.id/pir

p-ISSN: 2614-2325 dan e-ISSN: 2614-2317

DOI: https://doi.org/10.26858/pir.v2i2.10000

\title{
Persepsi Mayarakat Toraja Pada Upacara Adat Rambu Solo’ Dan Implikasinya Terhadap Kekerabatan Masyarakat Di Kecamatan Makale Kabupaten Tana Toraja
}

\author{
Grace Rima \\ Program Pascasarjana, Universitas Negeri Makassar \\ Email: gracerima2@gmail.com
}

\begin{abstract}
Abstrak. Tujuan penelitian ini adalah untuk mengetahui tentang (i) Struktur kelembagaan masyarakat adat Toraja, (ii) Persepsi masyarakat Toraja pada Upacara Adat Rambu Solo'; (iii) Implikasi pelaksanaan Rambu Solo' terhadap keeutuhan kekerabatan masyarakat di kecamatan makale kabupaten Tana Toraja. Penelitian ini adalah penelitian menggunakan kualitatif yang menggambarkan dan mendeskripsikan fenomena-fenomena yang realistis yang terjadi pada 'Masyarakat Toraja Pada Upacara Adat Rambu Solo' Dan Implikasinya Terhadap Kekerabatan Masyarakat". Metode pengumpulan data melalui observasi, wawancara dan dokumentasi. Hasil penelitian menunjukkan (i) Pusat kelembagaan Masyarakat Adat Tana Toraja adalah Tongkonan. Lembaga adat terdiri dari pemangku adat (To Parenge'), hakim adat dan tokoh-tokoh masyarakat yang saling bekerjasama dalam menjalankan fungsinya. (ii) Masyarakat Tana Toraja dalam menanggapi upacara adat Rambu Solo' beranggapan bahwa Rambu Solo' merupakan upacara adat khusus kedukaan/kematian dimana jiwa dan roh manusia yang telah meninggal kembali ke tempat semula. Pada awalnya ketika masyarakat Tana Toraja hidup di dalam kasta-kasta, tidak semua orang bisa melasanakan upacara adat Rambu Solo. Upacara ini hanya bisa dilaksanakan oleh kaum bangsawan (puang) dan kaum golongan atas (to sugi'), akan tetapi seiring dengan perkembangan zaman pandangan itu mulai bergeser sehingga upacara adat Rambu Solo' ini pun juga bisa dilakukan oleh para kaum golongan bawah (kaunan). (iii) Implikasi dari pelaksanaan Rambu Solo' terhadap keutuhan kekerabatan Masyarakat Di Kecamatan Makale Kabupaten Tana Toraja yaitu Membentuk nilai-nilai yang mempererat tali persaudaraan antar keluarga dan memiliki pengaruh yang sangat besar terhadap sistem kekerabatan antara keluarga dengan keluarga, keluarga dengan masyarakat dan masyarakat dengan masyarakat lainnya.
\end{abstract}

Kata Kunci : Persepsi Masyarakat, Upacara Adat Rambu Solo’, Sistem Kekerabatan

Abstract. The purposes of this research are to discover (i) the institutional structure of the traditional of Toraja people, (ii) the perception of Toraja people on the traditional ceremony of Rambu Solo', (iii) the the implication in implementing Rambu Solo' on the integrity of community relations in Makale subdistrict of Tana Toraja district. The type of this research is qualitative research which describes realistic phenomenon in "Tana Toraja people on traditional ceremony of Rambu Solo' and its implication on their kinship. The methods used in collecting the data are observation, interview, and documentation. The results of this research reveal that (i) the Institution Center of the indigenous people of Tana Toraja is 
Phinisi Integration Review. Vol 2(2) Agustus 2019

Tongkonan. The customary institutions consist of customary stakeholders (To Parenge), customary judges, and prominent people who work together to do their duty such as resolving conflicts and disputes that occur in society, preserving the traditional values, and enhancing the sense of kinship and mutual cooperation, (ii) the Tana Toraja people in responding traditional ceremony of Rambu Solo' state that it is a ceremony especially for funeral ceremony where the souls of the deceased return to their original place. The traditional ceremony carried out are based on ancestral beliefs, it is called Aluk To Dolo. Initially, when Tana Toraja people lived in different social status or castes, not all of them could carry out Rambu Solo' ceremony. This ceremony can only be held by noble people (Puang) and high class people (To Sugi'); however, along with the development of times, such opinion began to shift so the lower class people (Kaunan) can conduct this ceremony as well, (iii) The implementation of Rambu Solo' on the integrity of community relations in Makale subdistrict of Tana Toraja district is forming the values that strengthen the kinship among families and has huge influence on kindship system among families, family to society, and society to other society

Keywords: Perception of People, Tradisional Ceremony of Rambu Solo', Kinship System

Ini adalah artikel dengan akses terbuka dibawah licenci CC BY-NC-4.0

(https://creativecommons.org/licenses/by-nc/4.0/).

\section{PENDAHULUAN}

Negara Indonesia merupakan Negara hukum yang menjunjung tinggi keberadaan hukum itu sendiri. Hukum dalam kehidupan masyarakat berfungsi untuk mengatur dan mewaspadai atau bahkan mengatasi segala bentuk perubahan sosial maupun kebudayaan yang menggejala di masyarakat yang kompleks sekalipun. Undang-Undang Dasar Negara Republik Indonesia Tahun 1945 Pasal 1 ayat (3) kemudian mempertegas bahwa "Negara Indonesia adalah negara hukum". Untuk menciptakan suatu negara hukum, maka tentunya segala tindakan masyarakat tanpa terkecuali termasuk semua pemerintah harus berdasarkan pada hukum yang berlaku dan segala bentuk pelanggaran atau tindak kejahatan harus dikenakan sanksi. Segala bentuk tindakan yang dilakukan oleh warga masyarakat baik itu yang dilakukan secara sadar maupun tidak sadar, secara terus menerus dan berulang kali dilakukan sehingga menjadi sebuah kebiasaan pastilah ada aturan hukum yang mengaturnya.

Kebiasaan yang terus-menerus dilakukan dalam kehidupan masyarakat kemudian berkembang menjadi masyarakatmasyarakat hukum adat. Undang-Undang Dasar
Negara Repulik Indonesia Tahun 1945 pasal 18 B ayat (2) mengatur bahwa Negara mengakui dan menghormati kesatuan-kesatuan masyarakat hukum adat beserta hak-hak tradisionalnya.

Adat merupakan suatu kebiasaan dalam masyarakat yang dilakukan secara terusmenerus dan dipertahankan oleh semua pendukungnya. Kebiasaan yang bertahan selama bertahun-tahun dan telah berakar dan bertumbuh dalam hati nurani para anggota masyarakatnya, maka itu akan menjadi kebudayaan. Budaya merupakan identitas dan komunitas suatu daerah yang dibangun dari kesepakatan-kesepakatan sosial dalam kelompok masyarakat tertentu. Budaya dapat menggambarkan kepribadian suatu bangsa, sehingga budaya dapat menjadi ukuran bagi majunya suatu peradaban manusia.

Kebudayaan merupakan hasil dari ideide dan gagasan-gagasan yang akhirnya mengakibatkan terjadinya aktifitas dan menghasilkan suatu karya (kebudayaan fisik) sehingga manusia pada hakikatnya disebut mahkluk sosial. Setiap masyarakat di setiap daerah tentunya memiliki kebudayaannya masing-masing. Oleh karena itu, setiap masyarakat memiliki aturan hukum tersendiri yang tentunya berbeda satu sama lain. 
Perbedaan inilah yang menunjukkan bahwa setiap masyarakat memiliki ciri khas yang berbeda-beda. Kebudayaan juga yang telah membuat perbedaan antara bangsa Indonesia dengan bangsa lain, antara hukum bangsa Indonesia dengan hukum di negara lain. Dalam hal ini hukum khas bangsa Indonesia adalah Hukum Adat.

Adat merupakan gambaran sikap dan perilaku manusia yang telah berproses dalam jangka waktu yang lama dan dilaksanakan secara turun-temurun dari generasi ke generasi berikutnya. Adat juga mencakup aturan, prinsip, dan ketentuan-ketentuan kepercayaan yang terpelihara rapi yang diwariskan secara turuntemurun pada setiap generasi. Kekhususan adat dari tiap-tiap daerah didasarkan pada kepribadian dari daerah tersebut dimana dalam pelaksanaannya berkisar pada lingkaran hukum yaitu menyangkut kondisi dan peradaban masyarakat itu. Hal ini pun nampak dalam ungkapan yang menyatakan bahwa bila orang Bugis Makassar mengutamakan pesta pernikahan, maka orang Toraja lebih mengutamakan Upacara Kematian atau yang disebut dengan Upacara Rambu Solo'. Masyarakat Toraja sejak dahulu dikenal sebagai masyarakat religius dan memiliki integritas tinggi dalam menjunjung tinggi budayanya.

Masyarakat Tana Toraja memiliki upacara adat besar diantaranya Upacara "Rambu Solo" yaitu upacara kedukaan yang biasa disebut "Aluk to mate" atau upacara penguburan, sedangkan Upacara "Rambu Tuka" yaitu upacara adat yang berhubungan dengan acara syukuran dan penuh dengan kegembiraan dimana diadakan pemujaan korban kepada Tuhan dan dewata.

Bagi masyarakat Toraja, upacara Rambu Solo' merupakan tradisi yang paling tinggi nilainya dibanding dengan unsur budaya lainnya. Upacara Rambu Solo’ diatur dalam Aluk Rampe Matampu dan mempunyai sistem serta tahapan sendiri yaitu dalam upacara kedukaan dan kematian. Upacara Rambu Solo' merupakan salah satu aspek kehidupan yang dianut masyarakat Toraja yang pada awalnya sebagai kepercayaan "Aluk Todolo".

Aluk Todolo merupakan kepercayaan (agama) leluhur di Daerah Tana Toraja.
Keperayaan ini telah ada sebelum masuknya agama Islam dan Nasrani. Menurut kepercayaan Aluk Todolo, mati adalah suatu proses hidup manusia di dunia dan merupakan bayangan hidup kemudian karena apa yang dialami di dunia nyata akan dialami di alam gaib. Dalam tradisi suku Toraja, Upacara Rambu Solo' menjadi penting jika ditilik dalam perspektif Masyarakat Adat, kesempurnaan upacara kematian akan menentukan posisi arwah, apakah sebagai bombo (arwah gentayangan), tomembali puang (arwah yg mencapai tingkat dewa), atau deata (menjadi dewa pelindung). Dalam konteks ini, upacara kematian menjadi sebuah "kewajiban", maka dengan cara apapun orang Toraja hampir pasti akan mengadakan upacara tersebut, karena dengan begitulah mereka mengabdi kepada orang tua atau kerabat yang meninggal serta menjaga dan melestarikan budaya atau tradisi.

Berdasarkan Aluk Todolo seseorang yang telah meninggal dunia akan dikorbankan berupa kerbau dan babi sesuai dengan kemampuan keturunannya serta kaum kelurganya. Kemeriahan Upacara Rambu Solo' ditentukan oleh status sosial keluarga yang meninggal. Hal tersebut dapat diukur dari jumlah hewan yang dikorbankan. Semakin banyak hewan yang dikorbankan maka semakin tinggi pula status sosialnya. Namun seiring dengan perkembangan zaman, masyarakat sekarang sudah mulai bergeser dimana masyarakat tidak lagi berdasarkan pada kasta atau kedudukan, melainkan pada tingkat kekampuan perekonomian.

Bagi masyarakat Toraja, berbicara mengenai kematian bukan hanya tentang adat, upacara, kedudukan atau kasta, jumlah hewan yang akan disembelih, tetapi juga berbicara mengenai siri' (malu). Hal inilah yang kemudian mendasari masyarakat Toraja untuk berkomitmen menyelenggarakan upacara tersebut. Semua kerabat dan keluarga dituntut untuk terlibat langsung dalam kegiatan ini. Pada Upacara kematian tanpa ada persetujuan dari kerabat dan keluarga maka dapat mengakibatkan pertentangan dan perseteruan dalam lingkungan keluarga yang mengandung unsur tidak baik (terjadi pertentangan dan perselisihan) antar 
sanak-saudara serta keluarga dan kerabat lainnya.

Sistem kekerabatan merupakan kerangka interaksi antara anggota masyarakat yang merasa mempunyai hubungan kekerabatan. Pusat sistem kekerabatan adalah keluarga, baik keluarga inti (nuclear family) yang terdiri dari ayah, ibu dan anak-anak mereka, maupun keluarga luas (extended family) yang terdiri dari keluarga inti ditama kakek, nenek paman, bibi, para sepupu, kemanakan dan lain-lain.

Dalam sistem kekerbatan terdapat prinsip-prinsip keturunan (descent) yang mematasi keanggotaa kelompok kekerabatan itu. Kekerabatan adalah lembaga yang bersifat umum dalam masyarakat dan memainkan peranan penting dalam aturan tingkah laku dan susunan kelompok.

Sistem kekerabatan masyarakat Toraja memiliki sebuah karakteristik kekerabatan yang menguatkan persatuan dalam keluarga, hal ini dapat dilihat dari kekerabatan Toraja yang terbentuk dengan komposisi di setiap desa dimana terbentuk dari suatu keluarga besar. Dalam setiap satu keluarga besar atau yang disebut dengan Tongkonan, keluarga memiliki nama yang dijadikan nama desa. Sistem kekerabatan dalam masyarakat Toraja teerbagi atas kelurga inti. Ayah sebagai pemegang peranan utama dalam keluarga, sebagai penanggung jawab dalam keluarga, dan akan diganti anak laki-laki bila meninggal. Sedangkan ibu hanya mendidik dan memelihara anak serta nama baik keluarga. Dalam tatanan masyarakat Toraja, unsur terkecil dalam sistem kekerabatan disebut Siulu (keluarga batih). Jika anak dalam keluarga masyarakat Toraja lahir maka nama anak diberikan atas dasar kekerabatan, dan biasanya nama anak dipilih dari kerabat yang telah meninggal. Keunikan lain dari sistem kekerabatan masyarakat Toraja adalah mereka mengadopsi anak meskipun telah dikaruniai anak sebelumnya, hal itu dikarenakan masyarakat Toraja memiliki keyakinan bahwa semakin banyak anak akan semakin banyak pula toding atau kerbau yang akan dikurbankan saat orang tua angkatnya meninggal dunia.

Berdasarkan hasil observasi awal dengan salah satu Tokoh Adat yaitu Trija Putra Pamian yang merupakan pemandu adat Toraja atau yang disebut dengan Tomina, pada tanggal 9 Juli 2018 menyatakan bahwa dalam masyarakat Toraja dikenal adanya Strata atau golongan kasta diantaranya Tana' Bulaan, Tana' Bassi, Tana' Karurung dan Tana' kuakua

Keempat Kelompok sosial ini merupakan tatanan yang mengatur perilaku para anggota kelompoknya, termasuk memberi ciriciri yang khas dalam melaksanakan upacara Rambu Solo'. Bentuk upacara Rambu Solo' yang dilaksanakan di Tana Toraja disesuaikan dengan kedudukan sosial masyarakatnya. Oleh karena itu, upacara Rambu Solo' di Tana Toraja dibagi ke dalam empat tingkatan, di mana setiap tingkatan juga masih memiliki beberapa bentuk yaitu Upacara Disilli, Upacara Dipasangbongi, Upacara Dibatang atau Didoya Tedong, Upacara Rapasan.

Menurut Trija Putra Pamian makna dan nilai dari tradisi masyarakat Toraja terkhususnya Upacara Rambu Solo' sudah mulai bergeser seiring dengan modernisasi yang berkemang di masyarakat.

Persepsi masyarakat dalam menanggapi upacara adat sudah tidak lagi didasarkan pada syarat-syarat dan ketentuan yang berlaku tetapi mereka mulai mengenyampingkan syarat-syarat dan ketentuan tersebut dan berbuat sesuai kemauan dan kemampuan perekonomian mereka.

Dalam pelaksanaan Upacara Rambu Solo' semua pihak keluarga dan kerabat dihadirkan untuk berembuk dan membentuk panitia. Maka semua kerabat dan keluarga baik yang berdomisili di Tana Toraja maupun di luar Tana Toraja akan menyempatkan hadir mengikuti Upacara adat. Tanpa ada persetujuan dari pihak kerabat dan kelurga akan dapat mengakibatkan pertentangan baik dalam dalam harta benda dalam hal pewarisan maupun gejolak batin setiap individu-individu yang di tinggalkan, yang mengandung unsur tidak baik (perselisihan) antara sanak-saudara serta kelurga lainnya.

Merujuk pada fenomena tersebut, peneliti tertarik untuk melakuukan penelitian mengenai Persepsi Mayarakat Toraja Pada Upacara Adat Rambu Solo' Dan Implikasinya

Terhadap Kekerabatan Masyarakat Di 
Kecamatan Makale Kabupaten Tana Toraja. Dengan fokus penelitian ditujukan kepada masyarakat Toraja. Hal tersebut dilakukan untuk mengetahui dan memperoleh gambaran tentang keutuhan kekerabatan masyarakat Toraja pada Rambu Solo'.

Berdasarkan uraian diatas, peneliti bermaksud mengkaji lebih dalam melalui penelitian yang berjudul "Persepsi Mayarakat Tana Toraja Pada Upacara Adat Rambu Solo' Dan Implikasinya Terhadap Kekerabatan Masyarakat Di Kecamatan Makale Kabupaten Tana Toraja.

A. Rumusan Masalah

1. Bagaimana struktur kelembagaan masyarakat adat Tana Toraja?

2. Bagaimana persepsi dan pandangan masyarakat Toraja pada Upacara Adat Rambu Solo'?

3. Bagaimana implikasi pelaksanaan Upacara Adat Rambu Solo' terhadap kekerabatan masyarakat di kecamatan makale kabupaten Tana Toraja?

B. Tujuan Penelitian

1. Untuk mengetahui struktur kelembagaan masyarakat adat Toraja

2. Untuk mengetahui persepsi masyarakat Toraja pada Upacara Adat Rambu Solo'

3. Untuk mengetahui implikasi pelaksanaan Upacara Adat Rambu Solo' terhadap kekerabatan masyarakat di kecamatan makale kabupaten Tana Toraja

\section{Manfaat Penelitian}

1. Manfaat Teoritis

Penelitian ini diharapkan dapat memberikan kontribusi pemikiran dalam rangka pengembangan ilmu pengetahuan dan sekaligus menjadi acuan bagi penelitian serupa yang menelaah dan mengkaji mengenai Persepsi Mayarakat Toraja Pada Upacara Adat Rambu Solo' Dan Implikasinya Terhadap Kekerabatan Masyarakat.

2. Manfaat Praktis

Hasil penelitian ini diharapkan dapat menam bah pengetahuan dan wawasan bagi penyusun secara khusus dan pembaca pada umumnya serta dapat memberikan sumbangsih konkret sebagai bahan evaluasi kepada jajaran pemerintah dan masyarakat mengenai Persepsi Mayarakat Toraja Pada Upacara Adat Rambu
Solo' Dan Implikasinya Terhadap Kekerabatan Masyarakat.

\section{TINJAUAN PUSTAKA}

\section{A. Dasar Berlakunya Hukum Adat}

Dasar berlakunya hukum adat ditinjau secara yuridis dalam berbagai Peraturan Perundang-Undangan. Mempelajari segi yuridis dasar berlakunya hukum adat berarti mempelajari dasar hukum berlakunya hukum adat di Indonesia (Saragih, 1984:15).

\section{Undang-Undang Dasar Negara Republik Indonesia Tahun 1945}

Konstitusi Republik Indonesia yang diatur dalam UUD 1945 berlaku sejak tanggal 18 agustus 1945. Dasar hukum berlakunya hukum adat dalam UUD NRI Tahun 1945 ini adalah:

a. UUD NRI Tahun 1945 Pasal 18 B (2) yang mengatur bahwa "Negara mengakui dan menghormati kesatuan-kesatuan masyarakat hukum adat beserta hak-hak tradisionalnya sepanjang masih hidup dan sesuai dengan perkembangan masyarakat dan prinsip Negara Kesatuan Republik Indonesia, yang diatur dalam undang-undang".

b. UUD NRI Tahun 1945 Pasal 32 (1) yang mengatur bahwa "Negara memajukan kebudayaan nasional Indonesia di tengah peradaban dunia dengan menjamin kebebasan masyarakat dalam memelihara dan mengembangkan nilai-nilai budayanya". Pasal 32 (2) bahwa "Negara menghormati dan memelihara bahasa daerah sebagai kekayaan budaya nasional".

2. Undang-Undang Nomor 4 Tahun 2004 tentang Kekuasaan Kehakiman

Dasar hukum adat dalam UndangUndang Nomor 4 Tahun 2014 diatur di dalam pasal 25 (1) dan pasal 28 (1) yaitu sebagai berikut:

a. UU No. 4 Tahun 2004 pasal 25 (1) yang mengatur bahwa "Segala putusan pengadilan selain harus memuat alasan dan dasar putusan tersebut, memuat pula pasal tertentu dari peraturan perundang-undangan yang bersangkutan atau sumber hukum tak tertulis yang dijadikan dasar untuk mengadili"

b. UU No. 4 Tahun 2004 pasal 28 (1) yang mengatur bahwa "Hakim wajib menggali, mengikuti, dan memahami nilai-nilai hukum 
dan rasa keadilan yang hidup dalam masyarakat.

Kesadaran hukum merupakan suatu proses psikis yang yang terdapat dalam diri manusia, yang mungkin timbul dan mungkin juga tidak timbul. Jadi kesadaran hukum merupakan kesadaran atau nilai-nilai yang terdapat di dalam diri manusia tentang hukum yang ada atau tentang hukum yang diharapkan ada. Dengan demikian, jelaslah bahwa kesadaran hukum sebetulnya menjadi dasar bagi penegakan hukum sebagai proses. (Ishak, 2016 : 304)

\section{B. Pengertian Hukum Adat}

Hukum Adat adalah terjemahan dari istilah Belanda : "Adat-Recht", yang pertama kali dikemukakan oleh Snouck Hurgrounje pada tahun 1893 yang menyatakan bahwa hukum rakyat Indonesia yang tidak dikodifikasi artinya tidak tertulis dalam bentuk kitab undang-undang yang teratur susunannya. Istilah hukum adat (Dominikus Rato, 2011 : 3) berasal dari Bahasa Arab yang diadopsi oleh Snouck Hurgronje ketika ia menyamar menjadi Affan Gaffar untuk mengerti hukum Islam atau tepatnya hukum adat Aceh, yang kemudian dinamakan "Adhatrecht" yang kemudian dipopulerkan oleh Van Vollenhoven dan diimplementasikan oleh Ter Haar. Hukum adat menurut M.M Djojodigoeno (Dominikus Rato 2011 : 15) adalah "hukum yang tidak bersumber kepada peraturanperaturan. Maksudnya ialah bahwa hukum adat itu tidak bersumber dari peraturan perundangundangan yang dibuat oleh Lembaga Legislatif."

Hukum adalah suatu karya masyarakat tertentu yang bertujuan untuk menata menuju yang adil dalam perilaku dan perbuatan orang dalam perhubungan pamrihnya (bertujuan) serta kesejahteraan masyarakat itu sendiri yang menjadi substratumnya (dasar/alasnya).

Jadi adat istiadat diciptakan untuk mengatur tatanan kehidupan bermasyarakat, yang mencakup bidang yang sangat luas diantaranya tata cara berinteraksi antara kelompok-kelompok yang ada di masyarakat, apakah itu dalam perkawinan, kesenian, mata pencaharian, sistem kekerabatan dan sebagainya. Adat juga mencakup aturan prinsip, dan ketentuan-ketentuan kepercayaan yang terpelihara yang diturunkan secara turun- temurun pada setiap generasi. Hal ini pun tampak jelas dalam masyarakat Toraja yang yang dikenal sebagai daerah yang menjunjung tinggi adat budayanya.

Adat masyarakat Tana Toraja merupakan warisan budaya dunia ribuan tahun yang lalu, yang masih ada dan tetap dilestarikan serta menjadikan Tana Toraja sebagai obyek wisata. Pada umumnya upacara adat masyarakat Toraja kerap dilaksanakan dengan meriah dan besar-besaran terkhususnya pada upacara adat kematian (Rambu Solo').

\section{Konsep Persepsi}

Dalam Ensiklopedia Indonesia (Van Hoven, 1988: 866) dijelaskan bahwa yang dimaksud dengan persepsi adalah proses mental yang menghasilkan bayangan pada diri individu, sehingga dapat mengenal suatu obyek dengan jalan sosiasi dengan suatu ingatan tertentu baik secara indera penglihatan, indera peraba, dan sebagainya, sehingga akhirnya bayangan tersebut dapat disadari.

Menurut Mar'at (Mar'at, 1981: 21) menyatakan bahwa Persepsi adalah pengamatan seseorang yang berasal dari kelompok kognisi. Aspek kognisi merupakan aspek penggerak perubahan karena informasi yang diterima akan menentukan perasaan dan kemauan untuk berbuat. Jadi komponen kognisi akan berpengaruh terhadap predisposisi seseorang untuk bertidak senang atau tidak terhadap suatu objek, yang merupakan jawaban atas pertanyaan apa yang dipikirkan atau dipersepsikan tentang objek tersebut.

Jadi Persepsi merupakan suatu proses masuknya pesan atau informasi ke dalam otak atau alam pikiran manusia yang kemudian melahirkan pendapat-pendapat tertentu mengenai suatu objek.

\section{Hakikat Tradisi dan Kebudayaan \\ 1. Hakikat Tradisi}

Tradisi merupakan suatu gambaran sikap dan perilaku manusia yang telah berproses dalam waktu lama dan dilakukan secara turuntemurun dimulai dari nenek moyang. Tradisi yang telah membudaya akan menjadi sumber dalam berakhlak dan berbudi pekerti seseorang. Tradisi atau kebiasaan, dalam pengertian yang paling sederhana adalah sesuatu yang telah dilakukan untuk sejak lama dan menjadi bagian 
dari kehidupan suatu kelompok masyarakat, biasanya dari suatu negara, kebudayaan, waktu, atau agama yang sama. Hal yang paling mendasar dari tradisi adalah adanya informasi yang diteruskan dari generasi ke generasi baik tertulis maupun lisan, karena tanpa adanya ini, suatu tradisi dapat punah. Selain itu, tradisi juga dapat diartikan sebagai kebiasaan bersama dalam masyarakat manusia, yang secara otomatis akan mempengaruhi aksi dan reaksi dalam kehidupan sehari-hari para anggota masyarakat itu.

Di setiap wilayah atau daerah tertentu pasti memiliki kebiasaan-kebiasaan atau tradisi masing-masing yang kemudian disepakati bersama oleh seluruh anggota masyarakat. Berbicara masalah tradisi, tentu saja tidak terlepas dari konteks kebudayaan. Sebagaimana pendapat dari Koentjaraningrat (Noor Sulistyo Budi,1997: 1) yang memandang bahwa kebudayaan itu sebagai keseluruhan dari kelakuan dan hasil kelakuan yang harus didapatkan dengan cara belajar, dan yang kesemuanya itu tersusun dalam kehidupan masyarakat. Dengan demikian, tidak pernah ada masyarakat yang tidak mempunyai tradisi atau kebudayaan. Sebaliknya, tidak ada kebudayaan tanpa masyarakat yang sekaligus berfungsi sebagai wadah pendukung utamanya.

\section{E. Masyarakat Hukum Adat}

Masyarakat merupakan suatu bentuk kehidupan bersama, yang warga-warganya hidup bersama untuk jangka waktu yang lama, sehingga menghasilkan kebudayaan. Masyarakat merupakan sistem sosial, yang menjadi wadah dari pola-pola interaksi sosial atau hubungan interpersonal maupun hubungan nantar kelompok.

Masyarakat hukum adat menurut Ter Haar (Ter Haar 1937 : 87) adalah "Di seluruh kepulauan Indonesia pada tingkatan rakyat jelata, terdapat pergaulan hidup di dalam golongan-golongan yang bertingkah laku sebagai kesatuan terhadap dunia luar, lahir batin. Golongan-golongan / kelompok itu mempunyai tata susunan yang tetap dan kekal dan orangorang segolongan itu masing-masing mengalami kehidupan dalam golongan sebagai hal yang sewajarnya, dalam hal menurut kodrat alam. Tidak ada seorang pun dari mereka yang mempunyai pikiran akan kemungkinan pembubaran kelompok itu. Golongan masyarakat tersebut mempunyai pengurus sendiri dan harta benda, milik keduniaan dan milik gaib. Golongan-golongan yang demikian yangn bersifat persekutuan hukum."

Masyarakat hukum adat merupakan suatu kesatuan manusia sebagai satu kesatuan, menetap di suatu daerah tertentu, mempunyai penguasa-penguasa, mempunyai kekayaan yang berwujud atau tidak berwujud, di mana para anggota kesatuan hidup dalam masyarakat yang merupakan kodrat yang para anggotanya tidak berpikir untuk membubarkan ikatan tersebut atau melepaskan diri dari ikatan itu.

Dalam peraturan perundang-undangan di Indonesia, masyarakat hukum adat dirumuskan sebagai sekelompok orang yang terikat oleh tatanan hukum adatnya sebagai warga bersama suatu persekutuan hukum karena kesamaan adat tempat tinggal atapun atas dasar keturunan.

Menurut Soepomo (Soepomo 1977 : 51) masyarakat-masyarakat hukum adat di Indonesia dapat dibagi atas dua golongan menurut dasar susunannya, yaitu berdasarkan pertalian suatu keturunan (genealogi) dan yang berdasarkan lingkungan daerah (territorial).

Masyarakat hukum adat memeiliki fungsi seperti yang dinyatakan oleh Van Vollenhoven (Dominikus Rato 2011 : 86) adalah "Sebagai bingkai, dan di dalam bingkai inilah terdapat corak hukum adat". Berdasarkan bingkai itulah corak hukum adat pada masyarakat yang satu berbeda dengan coorak hukum adat pada masyarakat hukum adat lainnya.

\section{F. Arti Magis dan Animisme Upacara Adat Adat Rambu Solo'}

Di Indonesia, faktor magis dan animism memiliki pengaruh yang sangat besar, sehingga tidak dapat atau belum dapat hilang didesak oleh Agama, yang kemudian datang. Hal ini terlihat dalam wujud pelaksanaan-pelaksanaan upacara adat yang bersumber pada kepercayaan kepada kekuasaan-kekuasaan serta kekuatan-kekuatan gaib, yang dapat dimohon bantuannya.

Animisme (Zakiah Drajat, 1996 : 24) berasal dari kata anima, dari bahasa latin animus dan bahasa yunani anepos, dalam 
bahasa sansekerta disebut prana, dalam bahas ibrani ruah. Arti semua itu adalah napas atau jiwa. Animisme adalah ajaran/doktrin tentang realitas jiwa.

Dalam kamus bahasa Toraja (Bert $\mathrm{T}$. Lembang, 2012 : 99) Aluk adalah hal berbakti kepada Allah dan Dewa; upacara adat atau agama, adat istiadat; perilaku atu tingkah laku.

Aluk Todolo (Bert T. Lembang, 2012 : 100) merupakan Agama/kepercayaan leluhur orang Toraja). Alukta $=$ aluk nenek moyang todolota $=$ aluk kepunyaan kita. Aluk diciptakan oleh Puang Matua di atas langit, diturunkan melalui nene' manurun di Langi'pendahulu manusia Toraja, dipelihara dan diwariskan turun-temurun kepada anak-cucu.

Menurut Aluk Todolo, Upacara Rambu Solo atau upacara kematian yang dilaksanakan dengan keyakinan dan kepercayaan terhadap Todolo bahwa sesorang yang baru meninggal dunia rohnya masih menggembara disekitar rumah dan kampung tempat ia meninggal bahkan yang belum diupacarakan penguburannya masih diberi makanan dan disebut orang sakit yang pada prinsipnya bahwa sesudah orang meninggal dunia akan menjadi dewa (membali puang) dimana suatu proses kehidupan dalam roh manusia di alam nyata akan tetap sama di alam gaib, hanya saja tidak dapat dilihat atau diraba.

Upacara Rambu Solo' atau upacara adat kematian di Tana Toraja (Ibrahim Abbas, 1990:54-55) termasuk objek dinamis karena merupakan hasil budaya yang bergerak dan terus berjalan. Upacara yang merupakan pesta rakyat yang menarik bahkan mengesankan karena mempunyai nilai yang tinggi di dalam tatanan kehidupan orang Toraja baik sebagai anggota masyarakat maupun sebagai orang yang menganut berbagai kepercayaan. Pesta ini tetap dilakukan sebagai lambang kekayaan dan indentitas orang Toraja.

Bagi masyarakat Tana Toraja, Rambu Solo' dianggap sebagai sebuah "kewajiban" yang mau tidak mau harus dilaksanakan sebagai bentuk penghormatan dan pengabdian kepada manusia yang telah meninggal dunia.

\section{G. Sistem Kekerabatan di Indonesia}

Sistem kekerabatan terbentuk oleh karena manusia ingin mengetahui sejarah perkembangan kehidupan keluarga dalam masyarakat, sebagai suatu sistem sosial yang menyeluruh. Sistem kekerabatan (Ch. Winick 1975 : 302) merupakan terjemahan dari istilah kinship-systems (Bahasa Inggris) yaitu "The social recognition and expression of genealogical relationship, both consanguineal and affinal" yang diartikan sebagai suatu pengakuan dan ekspresi sosial dari hubungan genealogis, baik secara kekerabatan maupun afinitas.

Murdock (G.P Murdock 1965 : 92) berpendapat bahwa "sistem kekerabatan berbeda dengan organisasi sosial lainnya di dalam masyarakat. Suatu sistem kekerabatan bukanlah suatu kelompok sosial, serta tidak dikaitkan dengan suatu kumpulan individu-individu yang terorganisasikan."

Ikatan-ikatan kekerabatan berfungsi sebagai sarana untuk mengikat individu-individu tertentu, ke dalam kelompok-kelopok sosial, seperti keluarga dan keluarga besar.

\section{METODE PENELITIAN}

Jenis penelitian ini adalah kualitatif yang menggambarkan dan mendeskripsikan fenomena-fenomena yang realistis yang terjadi pada "Masyarakat Toraja Pada Upacara Adat Rambu Solo' Dan Implikasinya Terhadap Kekerabatan Masyarakat", khususnya bagi masyarakat di Kecamatan Makale Kabupaten Tana Toraja secara mendalam, guna menghasilkan data deskriptif bersifat uraian kata-kata -+atau makna-makna tertulis dari orang-orang atau responden yang diteliti dan dapat dipercaya serta memilih informan dari kepolisian yang memiliki pengetahuan lebih terhadap lalu lintas jalan.

Lokasi penelitian ini dilakukan di Kecamatan Makale Kabupaten Tana Toraja dan yang menjadi yang menjadi fokus dalam penelitian adalah sistem kekerabatan yang tetap terjalin pada mayarakat toraja yang bertempat tinggal di wilayah kecamatan makale kabupaten Tana Toraja pada saat melaksanakan upacara adat Rambu Solo'.

Dalam penelitian ini pemilihan lokasi dilakukan secara purposive (sengaja) yaitu ditetapkan secara sengaja oleh peneliti 
berdasarkan atas kriteria atau pertimbangan tertentu dalam penelitian ini dengan maksud agar dapat mendeskripsikan dan menginterpretasikan data dalam keadaan atau peristiwa sebagaimana adanya, sehingga bersifat mengungkap fakta.

Untuk mengumpulkan data, maka penulis menggunakan beberapa teknik sebagai berikut :

1. Observasi

Observasi digunakan untuk memperoleh data tentang tata cara pelaksanaan upacara adat Rambu Solo' dan persepsi masyarakat Toraja pada upacara adat Rambu Solo' guna menjawab rumusan masalah satu dan dua

2. Interview (Wawancara)

Interview (Wawancara) digunakan untuk memperkuat atau melengkapi data tentang tata cara pelaksanaan upacara adat Rambu Solo' dan persepsi masyarakat Toraja pada upacara adat Rambu Solo' untuk menjawab rumusan masalah dua dan tiga untuk mendapatkan data tentang implikasi pelaksanaan upacara adat Rambu Solo' terhadap keutuhan kekerabatan masyarakat di kecamatan makale kabupaten Tana Toraja untuk menjawab rumusan masalah ke dua.

3. Dokumentasi

Dokumentasi digunakan untuk memperoleh data dalam memperkuat hasil observasi dan wawancara guna menjawab rumusan masalah penelitian.

\section{HASIL DAN PEMBAHASAN}

\section{Struktur Kelembagaan Masyarakat Adat Tana Toraja}

Berdasarkan hasil wawancara yang dilakukan peneliti kepada lembaga pemerintahan dan masyarakatan ditemukan bahwa masyarakat adat Tana Toraja adalah masyarakat yang terbentuk karena adanya kesatuan geografis dan sosial beberapa wilayah adat yang disebut dengan $\mathrm{Bua}^{\prime}$. Bua' merupakan kesatuan wilayah-wilayah adat terkecil yang dipimpin oleh To Parenge' yang menjalankan sistem pemerintahan secara adat.

Lembaga adat terdiri dari pemangku adat (To Parenge'), hakim adat dan tokoh-tokoh masyarakat yang saling bekerjasama dalam menjalankan fungsinya. To Parenge' merupakan Jabatan yang diwariskan secara turun-temurun dari ahli waris sebelumnya dalam rumpun keluarga Tongkonan, yang berfungsi untuk mengurus dan menjaga harta pusaka seperti Rumah Tongkonan dan harta pusaka lainnya agartetap utuh dan terpelihara sehingga dapat terus menyatukan seluruh rumpun keluarga sedangkan hakim adat diatur oleh Badan Pemberdayaan Msyarakat dan Pemerintah Lembang atas rekomendasi dari Bupati Kabupaten Tana Toraja.

Berdasarkan data hasil wawancara dengan berbagai informan mengenai Struktur kelembagaan masyarakat adat Tana Toraja , maka dapat dipetakan atas;

1) Makna masyarakat adat Tana Toraja adalah sekumpulan masyarakat yang hidup bersama secara turun temurun di atas suatu wilayah adat. Dilihat dari prosesnya, dalam masyarakat adat lahir nilai-nilai luhur dan tradisi yang diakui dan dijaga keberadaannya sebagai pedoman untuk mengatur tatanan hidup masyarakat.

2) Struktur kelembagaan masyarakat adat Tana Toraja terbentuk karena adanya keinginan untuk mengatur kehidupan bermasyarakat dengan cara diadakannya rapat besar yang dibentuk oleh para Pemangku Adat dari masing-masing wilayah adat. Hal ini yang bertujuan untuk merapatkan mengenai tradisi dan kebiasaan masyarakat yang akan dijadikan sebagai acuan atau pandangan hidup masyarakat adat.

3) Struktur kelembagaan masyarakat adat Tana Toraja berpusat pada Tongkonan yang merupakan pusat kekuasaan dan pemerintahan adat yang memiliki fungsi dan peranan yang sangat penting dalam keberlangsungan kehidupan masyarakat seperti meningkatkan rasa kekeluargaan dan kegotong-royongan.

2. Faktor yang Mempengaruhi Tingkat Kepatuhan Hukum Berlalu Lintas Peserta Didik di Kota Makassar

Dari hasil penelitian yang dilakukan melalui wawancara kepada masyarakat, tokoh adat, tokoh agama dan pemerintah setempat di temukan bahwa Rambu Solo' merupakan 
upacara adat khusus kedukaan/kematian dimana jiwa dan roh manusia yang telah meninggal kembali ke tempat semula. Upacara adat yang dilakukan masyarakat dilandasi oleh kepercayaan atau keyakinan leluhur yang disebut Aluk Todolo.

Pada awalnya ketika masyarakat Tana Toraja hidup di dalam kasta-kasta, tidak semua orang bisa melasanakan upacara adat Rambu Solo. Upacara ini hanya bisa dilaksanakan oleh kaum bangsawan (puang) dan kaum golongan atas (to sugi'), akan tetapi seiring dengan perkembangan zaman pandangan itu mulai bergeser sehingga upacara adat Rambu Solo' ini pun juga bisa dilakukan oleh para kaum golongan bawah (kaunan).

Banyak dari kalangan tokoh adat, pemerintah setempat dan bahkan dari masyarakat sendiri menilai bahwa saat ini upacara adat Rambu Solo' sudah mengalami pergeseran. Ditemukan kesan ingin menonjolkan diri atau adu gengsi antar saudara dengan saudara, saudara dengan keluarga dan dengan masyarakat sekitar. di sisi lain pelaksanaan Rambu Solo' juga berdampak baik bagi kelangsungan hidup masyarakat seperti membuat masyarakat lebih bekerja keras, menguatkan nilai kekeluargaan, kerja sama dan kegotong-royongan antar keluarga dengan masyarakat sekitar, menumbuhkan sikap toleransi antar keluarga dan masyarakat yang berbeda keyakinan dan mempertinggi rasa solidaritas dan kesetiakawanan antar keluarga dan masyarakat.

\section{Implikasi Pelaksanaan Rambu Solo' terhadap Keutuhan Kekerabatan Masyarakat di Kecamatan Makale Kabupaten Tana Toraja}

Sebagaimana hasil penelitian melalui wawancara terhadap masyarakat, tokoh adat, tokoh agama dan pemerintah setempat bahwa dalam pelaksanaan Rambu Solo' mengandung nilai-nilai yang mempererat tali persaudaraan antar keluarga dan memiliki pengaruh yang sangat besar terhadap sistem kekerabatan antara keluarga dengan keluarga, keluarga dengan masyarakat dan masyarakat dengan masyarakat lainnya.

Nilai-nilai sosial yang terbentuk dalam pelaksanaan upacara adat Rambu Solo' ini, lama-kelamaan akhirnya menjelma menjadi tradisi dalam tata pergaulan masyarakat adat Toraja. Hal ini merupakan salah satu faktor penyebab upacara adat Rambu Solo' tetap bertahan di tengah zaman yang berubah.

Dalam pelaksanaan upacara adat Rambu Solo' mengandung nilai-nilai yang mempererat tali persaudaraan antar keluarga dan memiliki pengaruh yang sangat besar terhadap sistem kekerabatan antara keluarga dengan keluarga, keluarga dengan masyarakat dan masyarakat dengan masyarakat lainnya.

- Sebagai wadah pemersatu keluarga

- Sebagai tempat membagi warisan

- Sebagai tempat bergotong royong

\section{SIMPULAN DAN SARAN}

Dari uraian hasil penelitian maka ditarik kesimpulan sebagai berikut: (1) Pusat kelembagaan Masyarakat Adat Tana Toraja adalah Tongkonan. Lembaga adat terdiri dari pemangku adat (To Parenge'), hakim adat dan tokoh-tokoh masyarakat yang saling bekerjasama dalam menjalankan fungsinya seperti membantu menyelesaikan konflik dan sengketa yang terjadi dalam masyarakat, melestarikan nilai-nilai adat istiadat serta meningkatkan rasa kekeluargaan dan kegotongroyongan, (2) Masyarakat Tana Toraja dalam menanggapi upacara adat Rambu Solo' beranggapan bahwa Rambu Solo' merupakan upacara adat khusus kedukaan/kematian dimana jiwa dan roh manusia yang telah meninggal kembali ke tempat semula. Upacara adat yang dilakukan masyarakat dilandasi oleh kepercayaan atau keyakinan leluhur yang disebut Aluk Todolo. Pada awalnya ketika masyarakat Tana Toraja hidup di dalam kastakasta, tidak semua orang bisa melasanakan upacara adat Rambu Solo. Upacara ini hanya bisa dilaksanakan oleh kaum bangsawan (puang) dan kaum golongan atas (to sugi'), akan tetapi seiring dengan perkembangan zaman pandangan itu mulai bergeser sehingga upacara adat Rambu Solo' ini pun juga bisa dilakukan oleh para kaum golongan bawah (kaunan), (3) Terdapat dua implikasi dari pelaksanaan Rambu Solo' terhadap keutuhan kekerabatan Masyarakat Di Kecaatan Makale Kabupaten Tana Toraja yaitu a) Membentuk nilai-nilai yang mempererat tali 
persaudaraan antar keluarga dan memiliki pengaruh yang sangat besar terhadap sistem kekerabatan antara keluarga dengan keluarga, keluarga dengan masyarakat dan masyarakat dengan masyarakat lainnya. b) Memunculkan pertentangan-pertentangan seperti ketidaksepahaman prinsip, kecemburuan dan rasa rendah diri bahkan rasa kesombongan yang berdampak pada perpecahan dan ketidakutuhan antar saudara dengan saudara dan keluarga dengan keluarga lainnya

Dari kesimpulan penelitian, maka diajukan saran sebagai berikut: (1) Dengan berbagai macam keunikan proses pelaksanaan upacara adat Rambu Solo', diharapkan bagi masyarakat agar bisa mengubah cara pandang mereka untuk melangsungkan upacara adat Rambu Solo' sesuai dengan keadaan dan ketentuan yang telah ditetapkan sebelumnya, (2) Hendaknya dalam proses pelaksanaan Rambu Solo' mulai dari rapat sebelum pelaksanaan sampai pada tahap terahir yaitu penguburan, keluarga dan masyarakat dapat menyatukan hati dan pikiran sehingga tidak terjadi konflik dan pertentangan yang mengakibatkan pertentangan antar saudara dan keluarga.

\section{DAFTAR RUJUKAN}

Bushar Muhammad. 1997. Azas-azas Hukum Adat, Suatu Pengantar. Jakarta: Pradnya Paramita

Koentjaraningrat. 1967. Beberapa Pokok Antropologi Sosial. Jakarta: Penerbit Dian Rakyat.

Mar'at. 1981. Sikap Manusia, Perubahan dan Pengukurannya. Jakarta: Ghalia Indonesia.

Nort, D.C. 1993. Institution: Institution and Credibility Commitment. Journal of Institutional and Theoretical Economics.

Paranoan, M. 1995. Nilai-nilai Budaya Toraja, Dalam Laporan Forum Raya Konsolidasi Pariwisata Toraja.
Rato, Dominikus. 2011. Hukum Adat (Suatu Pengantar Singkat Memahami Hukum Adat di Indonesia). Yogyakarta: LaksBang PRESSindo.

Samosir, Djamanat. 2013. Hukum Adat Indonesia: Eksistensi Dalam Dinamika Perkembangan Hukum di Indonesia. Bandung : Nuansa Alia

Soekanto. 1955. Meninjau Hukum Adat Indonesia. Cetakan ke-3. Jakarta : Rajawali

Sugiono. 2010. Statistika Untuk Penelitian, cetakan keempat belas. Bandung : CV. Alfa Beta

Tallulembang, Bert. 2012. Reinterpretasi dan Reaktualisasi Budaya Toraja. Yogyakarta : Gunung Sopai Yogyakarta.

Ter Haar Bzn, B. 1937. Hukum Adat Hindia Belanda di dalam ilmu dan praktik dan pengajaran.

Tulak, Daniel. 2008. Kada Disedan Sarong Bisara Ditoke' Tambane Baka. Tana Toraja : Dinas Pariwisata Seni dan Budaya Kabupaten Tana Toraja.

Van VollenHoven, Cornelis. 1933. Het Adatrecht van Nederlandsch Indie, deel III. Leiden: E.J. Brill

Wignjodipuro, Surojo. 1973. Pengantar dan Azaz-azas Hukum Adat. Bandung : Alumni

Undang-Undang Dasar Negara Republik Indonesia tahun 1945

Undang-Undang Nomor 4 Tahun 2004 tentang Kekuasaan Kehakiman 